\title{
Protein Tyrosine Phosphatase 1B Inhibitors: Catechols
}

\author{
Jin Hee Alın, Sung Yun Cho, Jae Du Ha, Semg Kyu Kang, Sun Ho Jung, Hyc-Min Kim, \\ Sung Soo Kim, Kwang Rok Kim, Hyac Gyeong Cheon, Sung-Don Yang, and Joong-Kwon Choi
}

\author{
Medicinal Science Division. Korea Research Instinte of Chemical Technology. \\ 100. Jang-dong. Yuseong-gu, Daejeon 305-600, Korea \\ Received July 15. 2003
}

Key Words : Diabetes, PTPIB inhibitor, Catechol, I,2-naphthoquinone

As most intracellular signaling takes place via cascades of phosphorylation and dephosphorylation of tyrosines, protein tyrosine phosphatases have emerged as new and promising targets. Among them, protein tyrosine phosphatase 1B (PTP1B) negatively regulates insulin signaling by dephosphorylation of key tyrosine residues within the regulatory domain of the $\beta$-subunit of the insulin receptor, thereby atlenuating receptor tyrosine kinase activity.' Echelby et al. have demonstrated that PTP-1B knock-out mice led with high-fat dict showed enhanced insulin sensitivity without any adverse symptoms. ${ }^{2}$

Thus, PTP-1B inhibitor could potentially ameliorate insulin resistance and normalize plasma glucose and insulin without inducing hypoglycemia. ${ }^{3}$ Recently, small molecule inhibitors of PTP-1B as well as peptide mimetics were reported in literatures. They included catechol $\mathbf{A}, 0$-quinones $\mathbf{B}-\mathbf{D}$, and carboxylic acids E-G. ${ }^{+}$One of the inhibitors, Ertiprotafib (G) went to clinical trial, but was discontinued in Phase II<smiles>NCc1ccc(O)c(O)c1</smiles>

1

2<smiles>NC(Cc1ccc(O)c(O)c1)C(=O)O</smiles>
3<smiles>O=C1CCc2ccc(O)c(O)c2O1</smiles>

4<smiles>Oc1cc2ccccc2cc1O</smiles><smiles>Oc1ccc2ccccc2c1O</smiles>

6

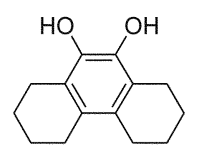

Figure 2. Catechol Derivalives.

due to insuflicient eflicacy and dose-dependent side elfects.

Some catechol derivalives were discovered as hits from high-throughput screening of the library of Korea Chemical Bank. ${ }^{5}$ s phenolic compounds with anti-oxidant activities are known to be benelicial in the treatment of diabetes and related disorders, and catechol $\mathbf{A}$ and similar compounds
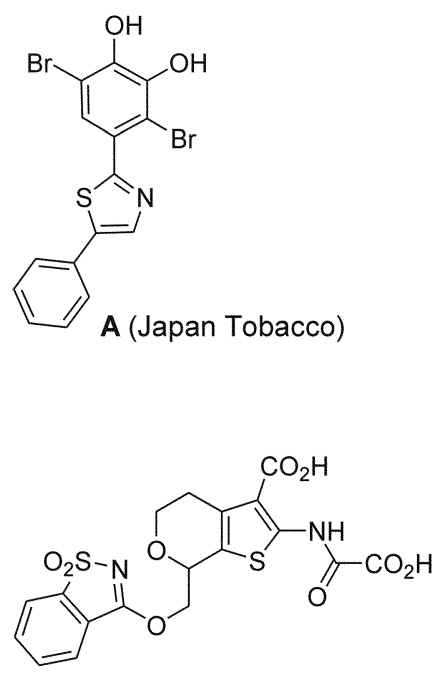

E (Ontogen \& Navo Nordisk)<smiles>CC(C)(C)OC(=O)COc1ccc(CC2=C(c3c[nH]c4ccccc34)c3ccccc3C(=O)C2=O)cc1</smiles>

B (KRICT)<smiles>CC1CC2=C(O1)c1cccc(O)c1C(=O)C2=O</smiles><smiles>CN1CCN(C2=CC(=O)C(=O)c3ccccc32)CC1</smiles>

D (Ontogen)<smiles></smiles>

F (Wyeth-Ayerst)<smiles>Cc1cc(-c2c3ccccc3c(Br)c3sc(C)c(C)c23)cc(C)c1OC(Cc1ccccc1)C(=O)O</smiles>

G (Ertiprotafib, Wyeth-Ayerst)

Figure 1. PTP-1B lnhibitors.

\footnotetext{
"Corresponding Author. E-mail: jkchoi $a$ krict.re.kr
} 
<smiles>O=C1CCCc2c1ccc(O)c2O</smiles><smiles>COc1ccc2c(c1OC)CCCC2=O</smiles>

8

c<smiles>COc1ccc2c(c1OC)CCC/C2=N\O</smiles>

12<smiles>CPC1CCCCC1</smiles>

d<smiles>COc1ccc2c(c1OC)CCCC2</smiles>

10<smiles>Oc1ccc2c(c1O)CCCC2</smiles>

11<smiles>[R]C1=C([Al])c2ccccc2C(=O)C1=O</smiles>

a. Ar=3-indolyl, $\mathrm{R}=\mathrm{H}$; b. $\mathrm{Ar}=\mathrm{Ph}, \mathrm{R}=\mathrm{CH}_{2} \mathrm{Ph}-4-\mathrm{OMe}$; c. $\mathrm{Ar}=3$-indolyl, $\mathrm{R}=\mathrm{CH}_{2} \mathrm{Ph}-4-\mathrm{OCH}_{2} \mathrm{CO}_{2}$-t-Bu

Scheme 1. Synthesis of Catechol Derivatives.

were reported to be $\mathrm{P}^{\mathrm{T}} \mathrm{T} \mathrm{P}-\mathrm{B}$ inhibitors, catechol derivatives were chosen to be tested as possible inhibitors of $\mathrm{P}^{[}[\mathrm{P}-\mathrm{IB}$.

First, commercially available catechols were tested. While 1-4 were not active and 2,3-naphthalenediol 5 showed moderate inhibition. 1,2-naphthalenediol 6 and octahydrophenanthrenediol 7 showed strong inhibition with $\mathrm{IC}_{50}$ of 1.25 and $3.65 \mu \mathrm{M}$, respectively. From these results, 1,2naphthalenediol seemed well suited for further study.

Thus, some related structures were prepared from 5,6dimethoxytetralone $\mathbf{8}$ as shown in Scheme 1." Simple demethylation gave dihydroxytetralone 9 . The tetralone 8 was reduced and demethylated to 11 and also converted to benzazepinone 14 by sequential treatment with hydroxyl-

Table I. Inbibitory Activily against P'P'P-113

\begin{tabular}{|c|c|c|c|c|c|}
\hline No & $\%$ inhibition & $\mathrm{IC}_{50}$ & No & $\%$ inhibition & {$\left[C_{50}\right.$} \\
\hline I & 4.4 & & 9 & 3.0 & \\
\hline 2 & 5.6 & & 11 & 23.9 & \\
\hline 3 & 1.0 & & 14 & na & \\
\hline 4 & 7.8 & & $16 \mathrm{a}$ & na & \\
\hline 5 & 49.6 & & $16 \mathrm{~b}$ & 97.6 & 3.89 \\
\hline 6 & 99.2 & 1.25 & $16 \mathrm{c}$ & 101.8 & 1.69 \\
\hline 7 & 66.5 & 3.65 & 17 & 109.4 & 1.61 \\
\hline
\end{tabular}

$\%$ inbibition at $20 \mu \mathrm{M}$ or $\mathrm{IC}_{\text {a }}(\mu \mathrm{M})$, na - not active amine, polyphosphoric aicd, and $\mathrm{BBr}_{3}$. Ketone 9 and lactam 14 were not active and only catechol 11 showed some activity. From this observation, the modification of aromatics to saturated hydrocarbons was detrimental to the activity of parent 1.2-naphthalenediols. Then 1.2-naphthoquinone 15a from the earlier work ${ }^{5}$ was reduced to 1,2-dihydroxynaphthalene 17 using phenyl hydrazine. ${ }^{?}$ As the catechol derivatives were easily oxidized back to naphthoquinone derivatives by atmospheric oxygen and metabolic instability was also expected, the acetylated derivatives $\mathbf{1 6}$ were prepared in one pot using zinc, sodium acetate, and acetic anhydride ${ }^{8}$ to implement the pro-drug character with stability. As expected from modest activities of catechols 7 and 11, diacetoxynaphthalene 16a showed low in vitro inhibitory activity. Unexpectedly, diacetoxynaphthalenes $16 \mathrm{~b}$ and $\mathbf{1 6 c}$ with substituents at 3-position showed remarkable in vitro activity, comparable to their naphthoquinone homologs." Also 1,2-naphthalenediol 17 substituted with 3indolyl group at 4 position showed the best inhibitory activity from this series.

Thus 17 was chosen for further study. As the selectivity of the inhibitors is important to minimize the undesirable side effects, the selectivity was tested against nine phosphatases and the result is shown in Table 2. The compound 17 showed better selectivity comapred to $\mathbf{F}$. Then 17 was also evaluated

Table 2. Isozyme Selectivity (IC $\left.\mathrm{I}_{50}, \mu \mathrm{M}\right)$

\begin{tabular}{ccccccccccc}
\hline & PIP-1B & Yop & VIIR & PPI & CI 45 & I.AR & ddc25A & edc25l3 & cde25C & PP2A \\
\hline 17 & 1.61 & $>>10$ & $>10$ & $>10$ & $>10$ & $>>10$ & $>10$ & 1.30 & $\cdots 10$ & $>10$ \\
F & 0.29 & 0.20 & 3.08 & 1.71 & 0.41 & $>10$ & 1.50 & 0.17 & 2.76 & $\cdots 10$ \\
\hline
\end{tabular}


Table 3. In wivo Efficacy

\begin{tabular}{ccccc}
\hline & 0 & $1 \mathrm{~d}$ & $3 \mathrm{~d}$ & $5 \mathrm{~d}$ \\
\hline $0.5 \%$ CMC & 100 & 100 & 100 & 100 \\
Rosiglitazone & 100 & 87 & 75 & 57 \\
17 & 100 & 90 & 99 & 53 \\
\hline
\end{tabular}

in vivo for their ability to reduce plasma glucose levels in the age- and sex-matched diabetic ob/ob mice $(n=4-6)$ at an oral dose of $25 \mathrm{mg} / \mathrm{kg} / 10 \mathrm{~mL}$ in $0.5 \% \mathrm{CMC}$. The plasma glucose level was reduced by $47 \%$ after 5 days of treatment.

In conclusion. a series of catechols were prepared and tested as PTP-IB inhibitors. The 4-(3-indolyl)-1.2-naphthalenediol (17) could reduce plasma glucose levels in the diabetic $o b \cdot o b$ mice by oral administration.

\section{Experimental Section}

5,6,7,8-Tetrahydronaphthalene-1,2-diol (11). A mixture of 5,6-dimethoxy-3.4-dihydro- $2 H$-naphthalen-1-one 8 (100 mg. $0.48 \mathrm{mmol})$ and $10 \% \mathrm{Pd} / \mathrm{C}(10.3 \mathrm{mg})$ in ethanol was hydrogenated for $\mathrm{l} h$ at $60 \mathrm{psi}$. The resulting mixture was filtered through Celite and concentrated to afford $81 \mathrm{mg}$ ( 87 $\%$ ) of 5.6-dimethoxy-1.2,3.4-tetralydronaphthalene 10: ${ }^{1} \mathrm{H}$ NMR $\left(200 \mathrm{MHz} . \mathrm{CDCl}_{3}\right) \delta 6.70-6.82(\mathrm{~m}, 2 \mathrm{H}), 3.85$ (s. $\left.3 \mathrm{H}\right)$. 3.81 (s. $3 \mathrm{H}) .2 .72-2.81(\mathrm{~m}, 4 \mathrm{H}), 1.73-1.79(\mathrm{~m} .4 \mathrm{H})$. To a solution of tetralin 10 (36 mg. $0.18 \mathrm{mmol})$ in methylene chloride was added $\mathrm{BBr}_{3}(0.50 \mathrm{~mL}, 0.90 \mathrm{~nm} o \mathrm{l})$ at $-78^{\circ} \mathrm{C}$. The resulting mixture was stirred for $0.5 \mathrm{~h}$ at $-78^{\circ} \mathrm{C}$ and 2.5 $h$ at room temperature followed by quenching with methanol at $-78^{\circ} \mathrm{C}$. The concentrated residue was purified by columm chromatography to afford catechol $11(23 \mathrm{mg} .75 \%)$ : ${ }^{1} \mathrm{H}$ NMR (200 MHz, $\left.\mathrm{CDCl}_{\hat{j}}\right) \delta 6.67-6.52(\mathrm{~m} .2 \mathrm{H}) .2 .71-2.65$ (m. $4 \mathrm{H}) .1 .81-1.76(\mathrm{~m} .4 \mathrm{H})$; EI-MS $m z$ (relative intensity) 164 $\left(\mathrm{M}^{+}, 98\right), 146(26), 136(100) .107(19) .91$ (18). 77 (23). 57 (28), 51 (23).

6,7-Dihydroxy-2,3,4,5-tetrahydro- $1 H$-benzoazepin-2one (14). A mixture of naphthalenone 8 (50 mg. $0.24 \mathrm{mmol}$ ). $\mathrm{NH}_{2} \mathrm{OH} \cdot \mathrm{H}_{2} \mathrm{O}$ (67 mg. $\left.0.97 \mathrm{mmol}\right)$. and $\mathrm{NaOAc}$ (80 mg. 0.97 mmol) in $3 \mathrm{~mL}$ of methanol and $1 \mathrm{~mL}$ of water was stirred for $6 \mathrm{~h}$ at $70^{\circ} \mathrm{C}$ and concentrated. The residue was purified by columu chromatography to afford oxime $12(50 \mathrm{mg} .93$ $\%$ ): ${ }^{1} \mathrm{H} \mathrm{NMR}\left(200 \mathrm{MHz}, \mathrm{CDCl}_{\mathfrak{j}}\right) \delta 7.65(\mathrm{~d}, J=8.8 \mathrm{~Hz}, \mathrm{lH})$. 6.80 (d. $J=8.8 \mathrm{~Hz}, 1 \mathrm{H}$ ). 3.89 (s. $3 \mathrm{H}$ ). 3.80 (s. $3 \mathrm{H}$ ). $2.70-2.85$ (m. $4 \mathrm{H}$ ), 2.82 (quint $J=6.2 \mathrm{~Hz}, 2 \mathrm{H}$ ). A mixture of oxime 12 (100 mg. $0.452 \mathrm{mmol}$ ) and $2.0 \mathrm{~g}$ of PPA was stirred at $125^{\circ} \mathrm{C}$ for $20 \mathrm{~min}$ followed by addition of ice water. The mixture was extracted with $\mathrm{CH}_{2} \mathrm{Cl}_{2}$. The organic layer was concentrated in vacto and the residue was purified by column chromatography to afford lactam $13(38 \mathrm{mg} .38 \%$ ): ${ }^{1} \mathrm{H} \mathrm{NMR}\left(200 \mathrm{MHz}, \mathrm{CDCl}_{3}\right) \delta 7.43$ (brs. $\left.1 \mathrm{H}\right) 6.70-6.85$ (m. 2H) 3.86 (s. $3 \mathrm{H}) 3.81$ (s. $3 \mathrm{H}) 2.87$ (t. $J=7.0 \mathrm{~Hz} 2 \mathrm{H}$ ). 2.10 2.40 (m. 4H): EI-MS $m z$ (relative intensity) $221\left(\mathrm{M}^{-} .100\right.$ ). 206 (23). 166 (51). 151 (75). To a solution of lactam 13 (144 mg. $0.65 \mathrm{mmol})$ in methylene chloride was added $\mathrm{BBr}_{3}(5.0$ mmol) at $-78^{\circ} \mathrm{C}$. The resulting mixture was stirred for $0.5 \mathrm{~h}$ at $-78{ }^{\circ} \mathrm{C}$ and $2.5 \mathrm{~h}$ at room temperature followed by quenching with methanol at $-78{ }^{\circ} \mathrm{C}$. The concentrated residue was purified by column chromatography to afford catechol 14 (113 mg. 90\%): ${ }^{1} \mathrm{H}$ NMR (200 MHz. CD $\left.{ }_{3} \mathrm{OD}\right) \delta$ $6.65(\mathrm{~d} . J=8.8 \mathrm{~Hz} . \mathrm{lH}) 6.45(\mathrm{~d} . J=8.8 \mathrm{~Hz}, \mathrm{lH}) 2.80(\mathrm{t} . J=$ $6.2 \mathrm{~Hz} .2 \mathrm{H}) \quad 2.40-2.10(\mathrm{~m}, 4 \mathrm{H})$ : EI-MS $m z$ (relative intensity) $193\left(\mathrm{M}^{+} .29\right) .138(42) .82(32), 80(38), 43(100)$.

4-(3-Indolyl)-1,2-diacetoxynaphthalene (16a). A mixture of 4-(3-indolyl)-1,2-naphthoquinone 15a (200 $\mathrm{mg} .0 .731$ mmol), $\mathrm{Zn}(720 \mathrm{mg})$. and $\mathrm{NaOAc}(240 \mathrm{mg})$ in acetic anlyydride $(20 \mathrm{~mL})$ was stirred for $12 \mathrm{~h}$ at room temperature. The resulting mixture was partitioned between ice water and methylene chloride and the organic layer was dried with $\mathrm{MgSO}_{4}$. and concentrated in vacto. The product was solidified by ether-hexane to afford 16a (180 mg. $70 \%$ ): ${ }^{1} \mathrm{H}$ NMR (200 MHz. $\mathrm{CDCl}_{3}$ ) $\delta 8.45$ (brs. $\mathrm{lH}$ ), 8.05 (d. $J=8.2$ Hz. $1 \mathrm{H}$ ). 7.90 (d. $J=8.2 \mathrm{~Hz}, \mathrm{lH}$ ), 7.57-7.11 (m, $8 \mathrm{H}), 2.52$ (s, 3H). 2.36 (s. 3H): EI-MS $m z$ (relative intensity) 359 (M', 11), $317(30), 275$ (100), $246(13) .43(49)$.

4-Phenyl-3-(4-methoxybenzyl)-1,2-diacetoxynaphthalene (16b) and 4-(3-indolyl)-3-(+-t-butoxycarbonylmethoxybenzyl)-1,2-diacetoxynaphthalene (16c) were prepared like 16a from corresponding quinones 15 in $40 \%$ and $46 \%$ yields. respectively.

16b: ${ }^{~} \mathrm{H}$ NMR $\left(200 \mathrm{MHz}, \mathrm{CDCl}_{2}\right) \delta 7.80-6.60(\mathrm{~m}, 13 \mathrm{H})$, $4.4 \mathrm{l}(\mathrm{s} . \mathrm{lH}) .3 .79(\mathrm{~s}, 3 \mathrm{H}) .3 .65(\mathrm{~s}, 2 \mathrm{H}), 2.42(\mathrm{~s}, 3 \mathrm{H}), 2.09(\mathrm{~s}$, $3 \mathrm{H}$ ); EI-MS $m z$ (relative intensity) $440\left(\mathrm{M}^{+} .7\right) .398(24)$, $356(74), 248(85), 219(100) .202$ (15). 189 (18).

16c: ${ }^{1} \mathrm{H}$ NMR (200 MHz. $\left.\mathrm{CDCl}_{3}\right) \delta 8.32$ (brs. $1 \mathrm{H}$ ). 7.80 (d. $J=8.2 \mathrm{~Hz} . \mathrm{lH}), 7.60-6.59(\mathrm{~m} .12 \mathrm{H}), 4.4 \mathrm{l}(\mathrm{s} . \mathrm{lH}) .4 .02-$ $3.76(\mathrm{~m} .2 \mathrm{H}), 2.42(\mathrm{~s}, 3 \mathrm{H}) .2 .10(\mathrm{~s}, 3 \mathrm{H}) .1 .47(\mathrm{~s}, 9 \mathrm{H})$. EI-MS $m z$ (relative intensity) $579\left(\mathrm{M}^{+}\right.$. 19). 537 (8). 481 (4). 439 (20). 287 (18). 57 (34). 43 (100).

4-(3-Indolyl)-1,2-dihydroxynaphthalene (17). Phenylhydrazine ( $79 \mathrm{mg} .0 .731 \mathrm{mmol}$ ) was added to a solution of 4 (3-indolyl)-1.2-naphthoquinone $15(200 \mathrm{mg} .0 .731 \mathrm{mmol})$ in acetonitrile $(10 \mathrm{~mL})$ at room temperature and the resulting solution was stirred for $2 \mathrm{~h}$ followed by evaporation to afford catechol 17 (197 mg. 99\%): ${ }^{1} \mathrm{H}$ NMR (200 MHz. DMSO- $d_{6}$ ) $\delta 11.31$ (s. $1 \mathrm{H}$ ). 9.31 (s. $1 \mathrm{H}) .8 .82$ (s. $2 \mathrm{H}$ ). $8.12-7.02$ (m. 10H): EI-MS $m z$ (relative intensity) $275\left(\mathrm{M}^{-}, 100\right), 246$ (17). 228 (29). 217 (18). 200 (9). 189 (11). 114 (33).

Biological Activity. The tests were performed against recombinant human PTP-1B using fluorescein diphosphate (FDP) as the substrate. The medium was $30 \mathrm{mM}$ Tris. 75 $\mathrm{mM} \mathrm{NaCl} .0 .67 \mathrm{mM}$ EDTA in $1 \mathrm{mM}$ DTT (pH 8.0) buffer with $20 \mu \mathrm{M}$ FDP. and $0.1 \mu \mathrm{g}$ of PTP-1B. After an hour at room temperature with inhibitor. the enzyme activity was determined by measuring the fluorescence of the product. fluorescein monophosphate (FMT) at $485 \mathrm{~nm}$ (excitation) and $538 \mathrm{~nm}$ (emission). $\mathrm{IC}_{5 i j}(\mu \mathrm{M})$ values were determined from direct regression curve analysis. Isozyme selectivity was determined likewise using appropriate phosphatases.

In wivo efficacy was evaluated in the age- and sex-matched diabetic $o b \cdot o b$ mice $(\mathrm{n}=4-6)$. Animals were treated p.o. with $0.5 \% \mathrm{CMC}$ (vehicle control), rosiglitazone (positive control. $10 \mathrm{mg} / \mathrm{kg} / 10 \mathrm{~mL}$ in $0.5 \% \mathrm{CMC}$ ) and $17(25 \mathrm{mg} / \mathrm{kg} / 10 \mathrm{~mL}$ in $0.5 \% \mathrm{CMC}$ ). Compounds were given at $10: 00$ am and blood 
were withdrawn on days 1,3 , and 5 at $2: 00$ pm through peri-orbital venous sinus using heparin-treated capillary tubes. Blood glucose levels were measured using Vitalab Selectra 2 (Vital Scientific. Spankeren, Netherlands) and representative data as \% inhibition compared to control are shown

Acknowledgements. The authors appreciate the financial support by Ministry of Science and Technology of Korea and Bioneer Corporation and the generous supply of chemical library by the Korea Chemical Bank.

\section{References}

1. Saltiel. A. R.: Kalm, C. R. Nattre 2001 HH. 799

2. Elchebly: M.: Payette P.: Michaliszyn. E.: Cromlish. W.: Collins.
S.: Loy: A. L: Normandin. D: Cheng, A.: Himms-Hagen, J.: Chan1. C.-C.: Ramachandrant. C.: Gresser. M. T.: Tremblay. M. L.: Kennedy. B. P. Science 1999. 283. 1544

3. Johnson1. T. O.: Ermolieff. J.: Tirousek. M. R. Natme Revien's Drug Disconery 2002. 1.696.

4. van Huijsduijnen, R. H; Bombrun. A: Swimnen. D. Drug Discovery Today 2002. 7. 1013

5. (a) Ahn. . . H.: Cho. S. Y.: Ha. J. D.: Chu. S. Y.: Tung. S. H.: Tung. Y. S.: Baek. J. Y.: Choi. I. K.: Shit1. E. Y.: Kan1. S. K.: Kim. S. S.: Cheonl. H. G.: Yang. S. D.: Choi. T.-K. Bioorg. Med Chem. Lett. 2002. 12. 1941. (b) Cho. S. Y.: Ahn. J. H.: Ha, J. D.: Kang. S. K.; Jung. S. H.: Kim, H.-M; Baek, J. Y; Han, S. S.: Shin, E. Y.: Kim, S. S.; Kim. K. R.: Cheon. H. G.; Yang. S. D; Choi. J.-K. Bull. Konam Chem. Soc. 2003 . in press.

6. Kumar. P. Ong. Prep. Proceed Inter. 1997. 29.477.

7. Christoffers. T.: Mann. A. Eur. J. Org. Chem. 2000. 1977.

8. Itoh. S.: Fukui. Y: Haranou. S.: Ogino. M.: Komatsu. M.: Ohshiro. Y. J. Org. Chem. 1992, 57, 4452. 